\title{
A Revision in the Monetary Base
}

\section{R. Alton Gilbert}

$\mathbf{T}$ HE Monetary Control Act of 1980 mandated a substantial change in the structure of reserve requirements faced by depository institutions. The reserve requirement structure was phased in over a sevenyear period from November 1980 to September 1987.

The adjusted monetary base, a measure of the Federal Reserve's influence on the money stock, has been revised to reflect this new structure. This article explains why the base series was revised and describes the difference between the previous and revised series.

\section{THE ADJUSTED MONETARY BASE: PURPOSE AND COMPOSITION}

The adjusted monetary base (AMB) is designed to be a single measure of all Federal Reserve actions that influence the money stock, including changes in reserve requirements. It is equal to the source base plus the reserve adjustment magnitude (RAM).

The source base consists of total currency outstanding theld by the public and in the vaults of depository institutions) plus the reserve balances of depository institutions at Federal Reserve Banks.' "The level of the money stock (currency in the hands of the public plus checkable deposits) that can be supported with a given level of the source base depends on reserve requirements. If required reserve ratios are reduced,

R. Alton Gilbert is an assistant vice president of the Federal Reserve Bank of St. Louis. Nancy D. Juen provided research assistance.

${ }^{t}$ Reserve balances of depository institutions included in the source base are net of required clearing balances and balances held to compensate for float. for example, a given level of the source base can support a higher level of the money stock.

RAM is specified in terms of the reserve requirements in effect in a base period. It equals the reserves that would be required (given current deposit liabilities) if the reserve requirements of a base period were in effect minus the reserves that are actually required. RAM rises (falls) if reserve requirements are lowered (raised). Including RAM in the AMB removes the effects of reserve requirement changes from the relationship between the money stock and the AMB, even though such changes affect the relationship between the money stock and the source base.

\section{THE IMPLICATIONS OF PESERV ACCOUNTUNG FOR AN APIPOPPTIATR MEASURE OF RAM}

The money stock is the product of the monetary base multiplier and the AMB. The issues involved in developing an appropriate measure of RAM can be analyzed in terms of the determinants of the monetary base multiplier. This section discusses the relationships between the structure of reserve requirements, the eauations for measuring RAM, and the determinants of the AMB multiplier. The appendix presents the specific equations used for measuring RAM and derives the determinants of the AMB multiplier associated with each specification.

The AMB measures all three policy actions that influence money growth: open market operations, discount window lending and changes in reserve ${ }^{-}$ quirements. The monetary base multiplier reflects the effects that choices of both depository institutions and the public have on the money stock. The determinants 
of the multiplier include the ratio of cumency in the hands of the public to checkable deposits, the composition of deposits and the excess reserves held by depository institutions.

These determinants depend on how RAM is measured. The appropriate specification of RAM, in tum, depends on the structure of reserve accounting in effect. This principle can be illustrated for two features of reserve accounting: the reserve requirements of members and nommembers and those on fime and savings deposits.

Prior to 1980, only banks that were members of the Federal Reserve were subject to the Fed's reserve requirements; nonmember institutions were exempt from these requirements." Thus, shifts of deposits bem tween members and nonmembers affected the level of deposits that could be supported by a given level of bank reserves. Also, since there were reserve require ments on the time and savings deposits of member banks, shifts of deposits between demand deposits and time and savings deposits at member banks affected the amount of checkable deposits that could be supported by a given level of bank reserves. Because these deposit shifts represented the public's rather than the Federal Reserve's actions, the AMB series was constructed so that the deposit shifts affected the AMB multiplier; the effects of these shifts are demonstrated algebraically in the appendix. This $A M B$ series was appropriate for periods before $1980 .^{3}$

The Monetary Control Act of 1980 , however, imposed identical reserve requirements on both member and nonmember institutions. With the new structure of reserve requirements fully phased in, as of September 1987 , a deposit shift between menbers and non-

\footnotetext{
Before 1980, state-chartered nonmember banks were subject to the reserve requirements of the state in which they were chartered. For information on the levels of the state reserve requirements and their effects, see Gibert and Lovati (1978) and Gilbert (1978).

Given the nature of the prior measure of RAM. some actions of the puplic, such as shifts of deposits among banks, did not affect the multiplier. The structure of reserve requirements on member bank deposits in effect prior to November 1972 was based on the location of member banks. Shifts of deposits among member banks in cities of different size changed the average reserve requirement on member bank deposits, but did not affect the AMB mutiolier.

Under the structure of reserve requirements adopted hn November 1972, there was a graduated structure of reserve requirements on demand deposits at member banks. Shifts of demand deposits between large and small member banks changed the average reserve requirement on member bank demand deposits. Changes in the average reserve requirement on member bank demand deposits did not affect the multiplier.
}

members no longer affects the amoun of checkable deposits that can be supponted with a given amoun of reserves." Mantaining the old RAM measure would contine to make the money mutiplier anction of the distribution of deposts between member and nonmenber institutions; his distinction, however, has no relevance under the curent system of reserve accounting. Thus, the curent measure of PAM must be charged to make the AMB multiplier invariant to these deposit shifts.

Under the new structure, the only categories of time and savings deposits subject to positive reserve requirements are Eurodollar liabilities and nonpersonal time and savings deposts with initial mantrities of 18 months or less." With these exceptions, shifts of deposits between checkable deposits and time and savings deposits do not affect the amount of checkable deposits that can be suppoted with a given amount of reserves. In the new equation for RAM, the base period reserve requirement on all time and savings deposits is zero. This feature removes the ratio of time and savings deposits to checkable deposits as a deteminant of the money multiplier.

There is a problem, however, with the use of this new equation for $\mathrm{AM}$ in measuring the $\mathrm{AMB}$ before 1980. The new equation eliminates as determinants of the AMB multiplier the distribution of deposits between members and nonmembers and the distribution of deposits at member banks berween demand deposits and time and savings deposits. This produces an undesmable revision in the time series relationship between the money stock and the AMB prior to 1980 .

\section{THE SOLUTION: LINK TWVO DIFFEREN AMB SERES TOGETIIDR}

The major challenge in revising the AMB series is creating a continuous series while mantaining the determinants of the $A M B$ multipher that are appropriate for periods both before and after November 1980. The solution is fo link together, at the week ending November 19, 1980, wo series based on diferent equations for RAM. (November 19, 1980, was the first reserve

One exception involves nonmember institutions in Hawail that were in operation on or before August 1, 1978 ; their reserve requirements will be phased in through January 1993

5 Also subject to reserve requirements are nonpersonal ineligible acceptances and obligations of affilates with initial maturity greater than seven days 
settlement week under the reserve requirements specified in the Monetary Control Act. Using seasonatly unadjusted observations for that week, the value of the AMu derived from the new equation for RAM is divided by the value based on the prior equation for RAM; that matio equals 0.9704 . The AMB for each period through November 12, 1980, based on the prior equation for RAM, is then multiplied by that ratio." This adjustment leaves unchanged the growth rates of the AMB series between any wo points in time prion to November 1980; it also adjusts the level of the AMB series prior to November 1980 to avoid a break in the series on that date due to the change in the equation for RAM.

The new measure of BAM alters the seasonal patterns in the AMB. The revised series is not seasonaly adjusted as one continuous series. Instead, the data through October 1980 are seasonally adjusted without incorporating data with the new measure of RAM, and the data since November 1980 are seasonally adjusted with observations based entirely on the new measure of RAM.

\section{THE DATA}

Table 1 presents quarterly growth rates of these series from 1981. As the table shows, the growth rates of these series generally rise and fall together, On average, the new series grew slightly faster than the old series over this period. Data are not presented for periods prior to November 1980 , since the construction of the revised series keeps the growth rates unchanged.

\section{CONCLUSIONS}

The revision of the adjusted monetary base (AMB) involves a new equation for the reserve adjustment magnitude (RAM, the component of the AMB that reflects the effects of changes in reserve requirements. The new measure of RAM reflects the structure of reserve requirements specified in the Monetary Control Act of 1980, which were phased in between $\mathrm{Nom}$ vember 1980 and September 1987.

${ }^{6}$ For a discussion of this method of linking together distinct measures of the AMB, see Tatom (1980).

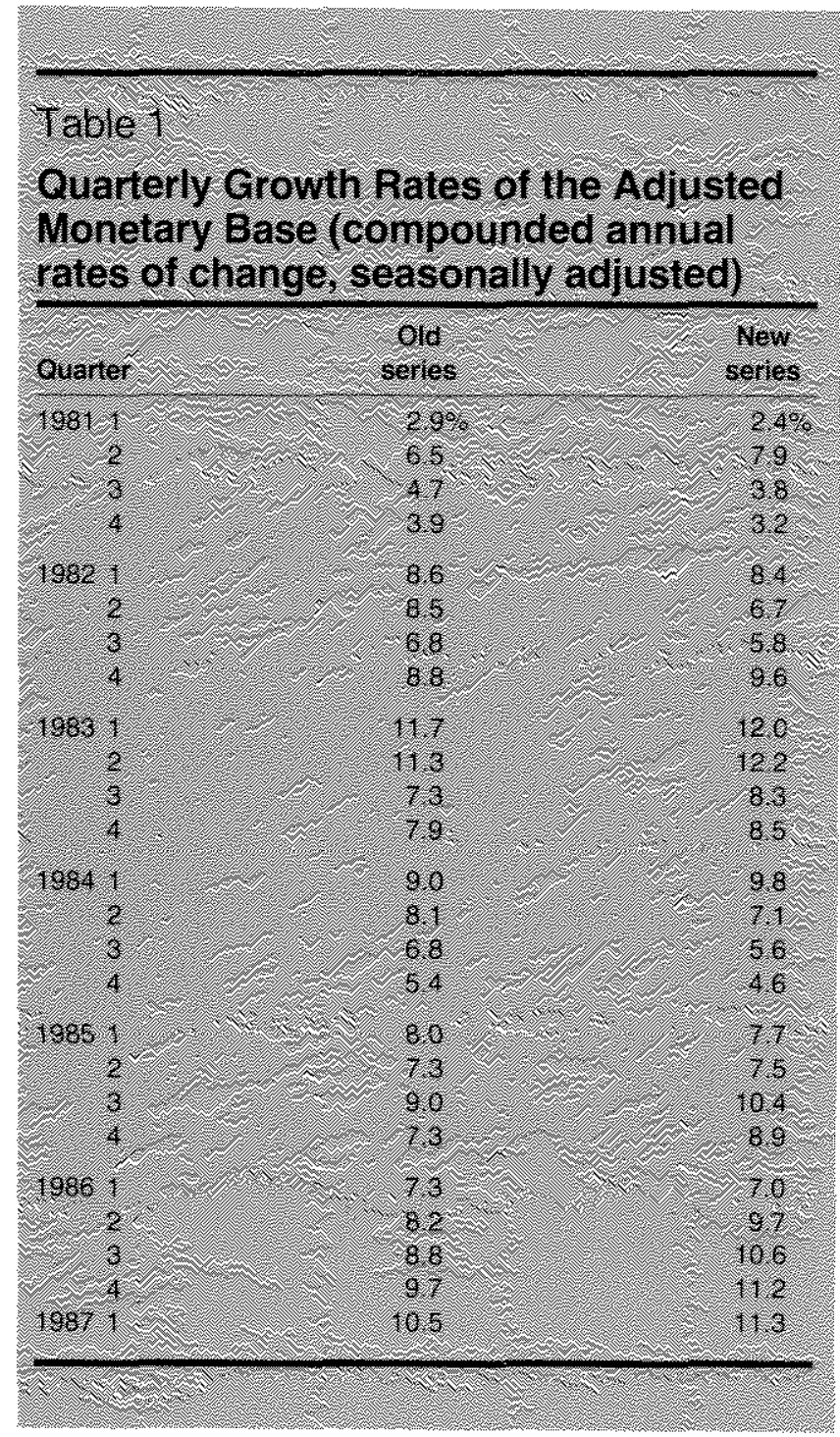

Data prior to November 1980 are calculated using the prior measure of RAM. In this revision of the AMB, therefore, the series through October $\mathbf{1 9 8 0}$ is distinct from the series from November 1980 to the present. The two distinct series are linked together in Novenber in a way that makes the revised AMB one continuous series. The prior measure of RAM is used for periods prior to November 1980 to retain the determinants of the monetary base multiplier (M1 $\div$ AMB that are appropriate for the reserve requirement structure then in effect. 


\section{REFERENCES}

Gilbert, R. Alton. "New Seasonal Factors for the Adjusted Monetary Base," this Review (December 1985), pp. 29-33.

. temporaneous Reserve Requirements," this Review (February 1984), pp. 27-32.

. . "Revision of the St. Louis Federal Reserve's Adjusted Monetary Base," this Review (December 1980), pp. 3-10.

n "Effectiveness of State Reserve Requirements," this Review (September 1978), pp. 16-28.
- and Jean M. Lovati, "Bank Reserve Requirements and Their Entocement: A Comparison Across States," this Review (March 1978), pp. 22-32.

and Michael E. Trebing. "The New System of Contemporaneous Reserve Requirements," this Review (December 1982), pp. 3-7.

Tatom, John A. "Issues in Measuring An Adjusted Monetary Base," this Review (December 1980), pp. 11-29. 


\section{Appendix \\ Two Equations for the AMB and the Corresponding Monetary Base Multipliers}

This appendix presents the equation for the AMB adopted in 1980 and the new equation that is now used to measure the $A M B$ for the period from November 1980 to the present. The determinants of the AMB multiplier are derived for each measure of the AMB. See table A1 for definitions of the terms used in specifying the AMB and its money multiplier.

\section{OLD MEASURE OF TUL AME}

In a revision of the monetary base in 1980 , the AMB was measured as follows:

$$
\text { (A1) } \begin{aligned}
\mathrm{AMB}_{1} & =\mathrm{SB}_{1}+0.12664\left(\mathrm{TDM}_{4-\mathrm{As}}\right. \\
& +0.031964\left[\mathrm{TSM}_{\mathrm{t}+14}-\mathbf{R R}_{\mathrm{t}}\right.
\end{aligned}
$$

The deposit data, which are for member banks only, are lagged 14 days to reflect the fact that the required reserves for each week were based on deposits of two weeks earier. The weights on the transaction deposits of member banks $(0.12664)$ and the time and savings deposits of member banks $(0.031964)$ are the average reserve requirements on these categories of deposits in the period from January 1976 through Akgust 1980.'

In deriving the multiplier associated with the AMB series specified in equation $A 1$, the time lags on the deposit data are ignored to simplify the equation. The first step in deriving the multiplier involves expressing the source base as the sum of its components.

$$
\begin{aligned}
(\mathrm{A} 2) \mathrm{SB}= & \mathrm{CP}+\mathrm{RR}+\mathrm{E} \\
\mathrm{AMB}= & \mathrm{SB}+\mathrm{RAM} \\
= & \mathrm{CP}+\mathrm{RH}+\mathrm{E}+0.12664(\mathrm{TDM})+ \\
& 0.031964(\mathrm{TSM})-\mathrm{RR} \\
= & \mathrm{CP}+\mathrm{E}+0.12664(\mathrm{CDM}+\mathrm{FM}+\mathrm{GM}) \\
(\mathrm{A} 3) \quad & 0.031964(\mathrm{TSM})
\end{aligned}
$$

Total checkable deposits, the deposit component of $\mathrm{M} 1$, equals the checkable deposits of members plus those of nonmembers. Using lower case " $n$ " as the fraction of checkable deposits at nonmembers, the components of the AMB in equation $A 3$ can be respecified as follows:

1 See Gibert ( 1980 ) for a description of this measure of the AMB.

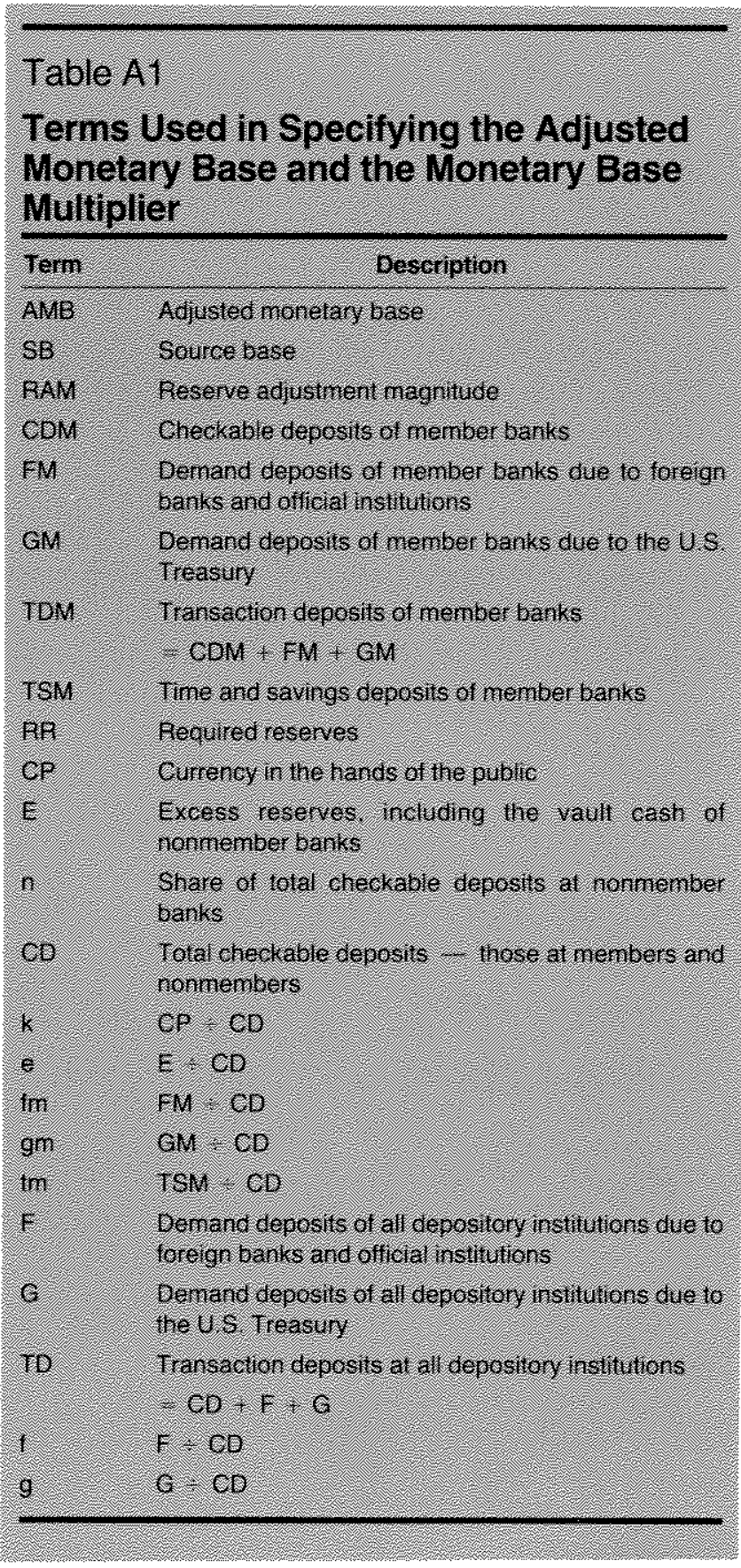




$$
\begin{aligned}
(A) A M B & =C D(k+e+0.12664(1)-n+f m+g m ! \\
& +0.031964 \text { (n) }
\end{aligned}
$$

The AMB mullipler can be specified as follows:

$$
\text { (A5) } \frac{\mathrm{MI}}{\mathrm{AMB}}=\frac{1+\mathrm{k}}{\mathrm{k}+\mathrm{e}+0.12664 \mathrm{n}-\mathrm{n}+\mathrm{m}+\mathrm{gm})}
$$

Thus given the equation for the AMB adopted in 1980, the AMB maltiplier is a function of:

1. the ratio of currency in the hands of the public to checkable deposits ( $\mathrm{k}$,

2. the ratio of excess reserves to checkable deposits $\{e\}$

3. the fraction of checkable deposits at nonmember institutions $[n\}^{2}$

4. the ratio of the demand deposits of member banks due to foreign banks and official institutions divided by total checkable deposits (m)

5. the ratio of the demand deposits of member banks due to the U.S. Treasury divided by total checkable deposits (gm), and

6. the ratio of time and savings deposits at member banks to checkable deposits (Tm).

The revised measure of the AMB prior to November 1980 is obtained by multiplying the measure described above by a specific ratio; this ratio is the level of the new measure of the AMB divided by the level of the prior measure for the week ering November 19, 1980. Multiplying the AMB specified above by this fixed ratio alters the level of the $A M B$ multiplier for periods prior to November 1980; however, this procedure leaves both its determinants and its growh rate unchanged.

\section{THE NEV MEASURE OR THE AMB}

\section{Reserve Accounting}

The timing of data in the new equation for calculating the $A M B$ is differen for the periods under lagged and contemporaneous reserve requirements. For the periods under lagged reserve requirements, that is, for the weekly reserve maintenance periods through the week ending February 1 , 1984, the $A M B$ is calculated as indicated in equation $A G$. "

\footnotetext{
2The deposit component of equation A6 is transaction deposits of all depository institutions for the week ending on a Wednesday, 14 days before the end of the current maintenance period. Historical data are no longer avaitable on transaction deposits for weeks ending on Wednesdays. When the Federat Reserve adopted contemporaneots reserve requirements in February 1984 , the weekly data series on deposits, currency and vault cash of depository institutions were converted from averages for weeks ending on Wednesdays to averages for weeks ending on Mondays. It is possible to derive a series for deposits in weeks ending on Wednesdays ( $\mathrm{TD}_{\mathrm{t}}{ }_{14}$ ) from the data on transaction deposits for weeks ending on the surroundity Mondays $\left(\mathrm{TQ} \mathrm{t}_{\mathrm{t}-19}\right.$ and $T D_{t-a}$, as indicated in the following equation:

$$
\mathrm{TD}_{\{-16}=(5 / 7) \mathrm{TD}_{-16}+(2 / 7) \mathrm{TD}_{i-9}
$$
}

Data on transaction deposits derived in this manner are used in the calcula tion of the AMB through February 1. 1984
(A6) $\mathrm{AMB},=\mathrm{SB}_{1}+10.121 \mathrm{TD}_{1-1 \mathrm{~d}}-\mathrm{RR}_{1}$

The base period reserve requirement on transaction deposits, 12 percent, is the marginal reserve requirement on most of the transaction deposits of depository institutions under the new structure of reserve requirements.

Contemporaneous reserve requirements became effective the week ending February 8,1984 . The method for calculating the AMB in this period is presented in equation A7.

$$
(\mathrm{A} 7) \mathrm{AMB}_{\mathrm{z}}=\mathrm{SB}_{\mathrm{q}}+(0.12) \mathrm{TO}_{1-2}-\mathrm{RR}_{\mathrm{t}}
$$

\section{Seasonal Ahjustment}

Contemporaneous reserve requirements altered the seasonal pattems of the AMB. In a previous revision of the AMB Gilbert 1985 described a method for deriving seasonal factors for the petiod after February 1984. That method is applied to this new series on the AMB. It involves developing a counterfactual series for weeks prior to February 1984 that reflects estimates of the seasonal patterns in the $A M B$ if contemporaneous reserve requirements had been in effect. The counterfactual series is calculated for the period lanuary 1975 through January 1984 . Observations for that series are combined with actual values of the AMB for the period since febtuary 1984 to derive seasonal factors that are used for seasonally adjusting the $A M B$ data for the period since February 1984

\section{The New AME Multiplier}

Using steps similar to those in equations $A 2$ and $A 3$, the new rneasure of the AMB can be spectied as follows:

(As) $\mathrm{AMB}=\mathrm{CP}+\mathrm{E}+0.12 \mathrm{CD}+\mathrm{F}+\mathrm{G}$

The AMB multiplier can be expressed as follows:

$$
\text { (A9) } \frac{\mathrm{M} 1}{\mathrm{AMB}}=\frac{1+\mathrm{k}}{\mathrm{k}+\mathrm{e}+0.12(1+\mathrm{f}+\mathrm{g})}
$$

The AMB multiplier, based on the new equation for the AMs fequations $A 6$ and $A 7$ ), is a function of:

1. the ratio of currency in the hands of the public to checkable deposits $[\mathrm{k}\}$,

2. the ratio of excess reserves to checkable deposits $\{\mathrm{e}\}$,

3. the ratio of demand deposits of depository institufions due to foreign commencial banks and official institutions to checkable deposits if , and

4. the ratio of U.S. Treasury deposits at depository instifu tions to checkable deposits (g).

3For a description of contemporaneous reserve requirements, see Gilbert and Trebing (1982). For an earlier discussion of the implications of contempora neous reserve tequirements for the measutement of RAM, see Gilbert (1984). 